
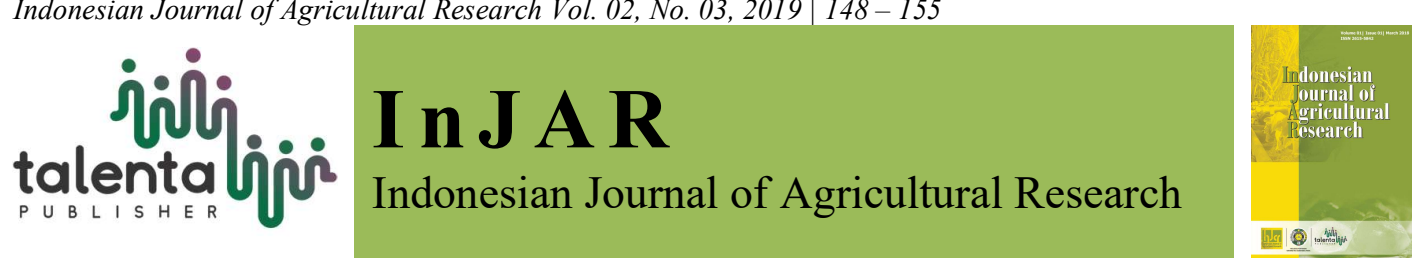

\title{
Streptomyces sp.: Characterization, Identification and Its Potential as a Ralstonia solanacearum Biological Control Agent in vitro
}

\author{
Rachmad Saputra ${ }^{1}$, Triwidodo Arwiyanto ${ }^{2}$, and Arif Wibowo ${ }^{2}$ \\ ${ }^{1}$ Department of Agrotechnology, Faculty of Agriculture, Universitas Riau, Indonesia \\ ${ }^{2}$ Department of Plant Pests and Diseases, Faculty of Agriculture, Gadjah Mada University, Indonesia
}

\begin{abstract}
Streptomyces sp. bacteria have the potential to produce antibiotic compounds, which are one of the mechanisms that are widely used in biological control. However, in general, biological control mechanisms also occur through competition, cell wall degradation and induced resistance. This study was aimed to determine the physiological, biochemical and molecular characteristics of two isolates of Streptomyces sp. (S-4 and S16 isolates) isolated from the tomatoes roots, and to find out their ability to control Ralstonia solanacearum, which causes bacterial wilt disease on a wide range of hosts. The results showed both Streptomyces sp. isolates had several different physiological and biochemical characteristics and had a different ability to inhibit $R$. solanacearum in vitro. Streptomyces sp. S-16 isolate had a high similarity with Streptomyces diastaticus subsp. ardesiacus strain NRRL B-1773T based on the molecular identification results. Further research needs to be done to see the potential inhibition of the two Streptomyces isolates in inhibiting the development of bacterial wilt disease in tomato plants caused by $R$. solanacearum.
\end{abstract}

Keywords: biological control agent, Ralstonia solanacearum, Streptomyces sp.

Received 06 September 2019 | Revised 14 October 2019 | Accepted 14 December 2019

\section{Introduction}

Streptomyces is a genus of Gram-positive bacteria that belongs to the phylum Actinobacteria. In many ways, these bacteria resemble filamentous fungi, which form vegetative mycelium and spread through spores formed in special reproductive structures called air hyphae, which emerge from the surface and point upwards. Most Streptomyces live as saprophytes in the soil [1].

Streptomyces are aerobic, saprophytic and mesophilic in their natural habitat in the soil. Some Actinomycetes members produce important secondary metabolites, including antibiotics, siderophores, enzymes and plant growth triggers that can contribute to their host plants by helping to accelerate growth and enhance the ability of plants under environmental stress conditions [2]. About $80 \%$ of useful antibiotics are derived from antibiotics produced by the

\footnotetext{
*Corresponding author at: Agrotechnology Department, Faculty of Agriculture, Universitas Riau. Jl. H.R. Soebrantras, Pekanbaru, Riau, Indonesia

E-mail address: rachmadsaputra@lecturer.unri.ac.id
} 
species Streptomyces [3] which are also potentially antagonistic and are toxic to several pathogens [4].

Several studies have reported that in vitro, Streptomyces has shown good results in suppressing some root pathogens [5]. Streptomyces pluricolorescens which are endophytic actinomycetes isolated from tomato plants in Brazil showed $86.6 \%$ of antimicrobial activity that could fight pathogens in tomato plants [6]. Another research report also stated that the antagonistic mechanism of Streptomyces as a biological control agent for bacterial wilt disease is the mechanism of antibiosis by producing antibiotics [7].

Ralstonia solanacearum is a soil-borne plant pathogenic bacteria that is commonly found in subtropical and tropical regions which naturally infects roots, reproduces itself in xylem tissue and has a very broad host range [8] [9]. Its ability to survive in the soil causes many control efforts that show limited success, such as cultivation techniques, resistant varieties, and soil fumigation [8] [10]. Therefore, the use of biological agents such as Streptomyces sp. needs to be studied further because this bacteria has the potential to produce antibiotic compounds. However, in general, biological control mechanisms also occur through competition, cell wall degradation and induced resistance.

\section{Materials and Methods}

The study was conducted at the Plant Bacteriology Laboratory, Faculty of Agriculture, Gadjah Mada University. Antagonistic bacteria used were Streptomyces sp. S-4 and S-16 isolated from the rhizosphere of tomato plants and isolate of Ralstonia solanacearum isolated from roots of eggplant. The data obtained were analyzed descriptively and displayed in tables and figures.

\subsection{Physiological and Biochemical Characterization of Streptomyces sp.}

Characterization and identification of the bacteria Streptomyces sp. consisted of molecular physiological and biochemical tests referring to Lelliot and Stead [11], Williams et al. [4] and Chun and Vidaver [12]. Physiological and biochemical characterization included Gram staining, catalase, oxidase, oxygen demand (oxidative-fermentation), gelatin hydrolysis, starch, levan formation, Voges Proskauer test, arginine dehydrolase, motility, tolerance of bacterial growth at several temperatures, $\mathrm{pH}$ and $\mathrm{HCl}$ concentration, the use and amendment of carbon, citrate and nitrogen compounds.

\subsection{Molecular Identification of Streptomyces sp.}

Bacterial DNA was extracted and isolated using the method according to Berlian [13]. The DNA was identified molecularly by PCR technique using16S rDNA universal pair primers, i.e. 63F (5'-CAG GCC TAA CAC ATG CAA GTC-3') and 1378R (5'-GGG CGG WGT GTA CAA GGC-3') with product targets measuring $1300 \mathrm{bp}$. The PCR products were then sequenced using 
BLAST (Basic Local Alignment Search Tool) in the National Center for Biotechnology Information (NCBI) website to determine the closest kinship level with bacteria in the GenBank database.

\subsection{In vitro Antagonism Test of Ralstonia solanacearum}

Antagonism test was carried out in vitro with a technique developed by Arwiyanto [14]. Streptomyces sp. cultures were incubated for 96 hours at $29^{\circ} \mathrm{C}$ in Yeast Peptone Glucose Agar (YPGA) medium. The petri dish reversed and $1 \mathrm{ml}$ of chloroform was added, then left for 2 hours at room temperature. After the chloroform has evaporated, the petri dish was turned in original position, then a $200 \mu \mathrm{l}$. solanacearum suspension in $4 \mathrm{ml} 0.6 \%$ water agar poured. Culture was incubated for 24 hours at $29^{\circ} \mathrm{C}$ to observe the inhibition zone. The isolates that produced inhibiting compounds were characterized by the presence of inhibition zones around the colonies of the antagonistic bacteria (Streptomyces sp.). Inhibition zones were measured and expressed in millimeters.

Detection mechanism of inhibition was done by taking clear agar in the inhibition zone and put in a test tube containing $5 \mathrm{ml}$ of $0.5 \%$ peptone solution and incubated aerobically for 24 hours at room temperature. Clear peptone solution shows that the inhibition of growth was bactericidal, while puddly peptone solution indicates inhibition was bacteriostatic [14].

\section{Results and Discussion}

\subsection{Physiological and Biochemical Characterization of Streptomyces sp.}

The physiological and biochemical characteristics of both isolates of Streptomyces sp. were almost similar (Table 1). However from several assays, the results showed differences. Streptomyces sp. S-4 isolate were able to hydrolyze gelatin, could grow at low temperature $\left(4^{\circ} \mathrm{C}\right)$ and $\mathrm{pH} 4$, whereas Streptomyses sp. S-16 isolates did not show the same ability. This indicates that Streptomyces sp. S-4 isolate can produce proteolytic enzymes. Gelatin hydrolysis test shows the presence of proteolytic enzymes that can hydrolyze proteins in gelatinous fluid [15].

The data in Table 2 shows that there are differences between the two isolates of Streptomyces sp. on the use of several carbon sources, citrate and nitrates assays. Streptomyses sp. S-4 isolate was able to remodel all carbon sources and citrate. In contrast,Streptomyses sp. S-16 isolate was not able to remodel the Trehalosa, Dulcitol and Sorbitol as carbon source, but could reduce nitrates. This reaction indicates that the presence of the enzyme oxidoreductase play a role in converting nitrates into nitrites, ammonia and nitrogen gas [15]. 
Tabel 1.Physiological and Biochemical Properties of Streptomyces sp.

\begin{tabular}{|c|c|c|}
\hline \multirow{2}{*}{ Assay Parameters } & \multicolumn{2}{|c|}{ Streptomyces sp. isolates } \\
\hline & S-4 & S-16 \\
\hline Gram staining & + & + \\
\hline Catalase test & + & + \\
\hline Oxidase Test & + & + \\
\hline Oxidative/Fermentative & Fermentative & Fermentative \\
\hline Gelatin hydrolysis & + & - \\
\hline Starch hydrolysis & - & - \\
\hline Levan form & - & - \\
\hline Vogestest & - & - \\
\hline Arginine Dehydrolase & - & - \\
\hline \multicolumn{3}{|l|}{ Growth on: } \\
\hline $\mathrm{NaCl} 1.0 \%$ & + & + \\
\hline $\mathrm{NaCl} 2.0 \%$ & + & + \\
\hline $\mathrm{NaCl} 4.0 \%$ & + & + \\
\hline $\mathrm{NaCl} 6.0 \%$ & + & + \\
\hline $\mathrm{NaCl} 8.0 \%$ & + & + \\
\hline $\mathrm{NaCl} 10.0 \%$ & + & + \\
\hline $\mathrm{NaCl} 12.0 \%$ & + & + \\
\hline Temperature of $4 \mathrm{oC}$ & + & - \\
\hline Temperature of $15 \mathrm{oC}$ & + & + \\
\hline Temperature of $260 \mathrm{C}$ & + & + \\
\hline Temperature of $30 \mathrm{oC}$ & + & + \\
\hline Temperature of $40 \mathrm{oC}$ & - & - \\
\hline $\mathrm{pH} 4$ & + & - \\
\hline $\mathrm{pH} 5.5$ & + & + \\
\hline $\mathrm{pH} 7$ & + & + \\
\hline $\mathrm{pH} 8.5$ & + & + \\
\hline pH 10 & + & + \\
\hline
\end{tabular}

Note: -: negative reaction, + : positive reaction

Tabel 2. Utilization of Carbon, Citrate and Nitrogen Compounds by Streptomyces sp.

\begin{tabular}{lcc}
\hline \multicolumn{1}{c}{ Assay Parameters } & \multicolumn{2}{c}{ Streptomyces sp. isolates } \\
\cline { 2 - 3 } & S-4 & S-16 \\
\hline Carbon sources utilization and remodel: & & + \\
Arabinose & + & + \\
Dextrose & + & + \\
Sucrose & + & + \\
Maltose & + & + \\
Fructose & + & + \\
Glucose & + & + \\
Galactose & + & + \\
Lactose & + & + \\
Trehalosa & + & - \\
Dulcitol & + & - \\
Sorbitol & + & + \\
Citrate Utilization & & \\
Nitrogen compounds remodel: & - & \\
Nitrate reduction & &
\end{tabular}

Note: -: negative reaction, + : positive reaction 


\subsection{Molecular Identification of Streptomyces sp.}

Visualization of the amplification of all Streptomyces sp. isolates using universal primers $63 \mathrm{~F}$ and 1378R showed the presence of parallel DNA bands at size of $\pm 1300 \mathrm{bp}$ (Figure 1). Homology of S-16 isolates based on 16S rDNA genes was related to Streptomyces diastaticus subsp. ardesiacus strain NRRL B-1773, Streptomyces coelicoflavus strain NBRC 15399 with homology reaching $99 \%$ (Table 3).

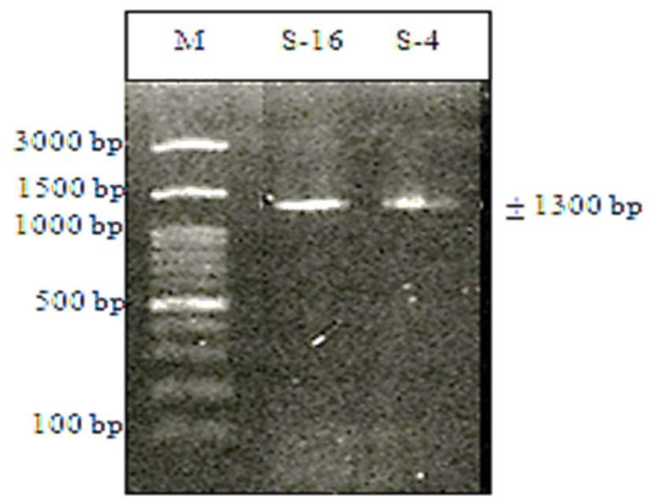

Figure 1. PCR products of Streptomyces sp. DNA. on agarose gels with a target size of

$$
\pm 1,300 \mathrm{bp} \text {. }
$$

Table 3. Streptomyces sp. S-16 Isolate Similarity based on the Sequence Analysis Derived from BLAST in NCBI website

\begin{tabular}{|c|c|c|c|c|}
\hline Description & $\begin{array}{l}\text { Max } \\
\text { Score }\end{array}$ & $\begin{array}{l}\text { Total } \\
\text { Score }\end{array}$ & $\begin{array}{l}\text { Query } \\
\text { Cover }\end{array}$ & $\begin{array}{l}\text { Percent } \\
\text { Identity }\end{array}$ \\
\hline $\begin{array}{l}\text { Streptomyces diastaticus subsp. ardesiacus strain } \\
\text { NRRL B-1773 }\end{array}$ & 2266 & 2266 & $100 \%$ & $99.21 \%$ \\
\hline Streptomyces coelicoflavus strain NBRC 15399 & 2263 & 2263 & $100 \%$ & $99.13 \%$ \\
\hline Streptomyces rubrogriseus strain NBRC 15455 & 2224 & 2224 & $100 \%$ & $98.57 \%$ \\
\hline Streptomyces hyderabadensis strain OU-40 16S & 2222 & 2222 & $100 \%$ & $98.57 \%$ \\
\hline Streptomyces fragilis strain NBRC 12862 & 2222 & 2222 & $100 \%$ & $98.57 \%$ \\
\hline Streptomyces tricolor strain NBRC 15461 & 2218 & 2218 & $100 \%$ & $98.50 \%$ \\
\hline Streptomyces lienomycini strain NBRC 15425 & 2218 & 2218 & $100 \%$ & $98.50 \%$ \\
\hline Streptomyces anthocyanicus strain NBRC 14892 & 2218 & 2218 & $100 \%$ & $98.50 \%$ \\
\hline Streptomyces violaceolatus strain NBRC 13101 & 2218 & 2218 & $100 \%$ & $98.50 \%$ \\
\hline Streptomyces humiferus strain NBRC 12244 & 2218 & 2218 & $100 \%$ & $98.50 \%$ \\
\hline Streptomyces coelescens strain AS 4.1594 & 2218 & 2218 & $100 \%$ & $98.50 \%$ \\
\hline Streptomyces violaceoruber strain DSM 40049 & 2218 & 2218 & $100 \%$ & $98.50 \%$ \\
\hline Streptomyces aurantiogriseus strain CSSP525 & 2218 & 2218 & $100 \%$ & $98.50 \%$ \\
\hline Streptomyces albogriseolus strain DSM 40003 & 2218 & 2218 & $100 \%$ & $98.50 \%$ \\
\hline
\end{tabular}

\subsection{In vitro antagonism test of Streptomyces sp. against Ralstonia solanacearum}

The results of in vitro antagonism test showed that Streptomyces sp. S-4 isolate could produce a inhibition zone (clear zone) of $4.53 \mathrm{~mm}$, while there was no inhibition zone was formed with S-16 isolate. The formation of this inhibition zone indicates the mechanism of antibiosis against R. solanacearum (Table 4, Figure 2 ). 
Table 4. Formation of Inhibition Zones of Streptomyces sp. against R.solanacearum in vitro

\begin{tabular}{ccc}
\hline Streptomyces sp. isolate & $\begin{array}{c}\text { Inhibition Zones } \\
(\mathbf{m m})\end{array}$ & $\begin{array}{c}\text { Mechanism of } \\
\text { Inhibition }\end{array}$ \\
\hline S-4 & 4.53 & Bacteriostatic \\
S-16 & nd & nd \\
\hline
\end{tabular}

Note: nd $=$ inhibiton zone not detected
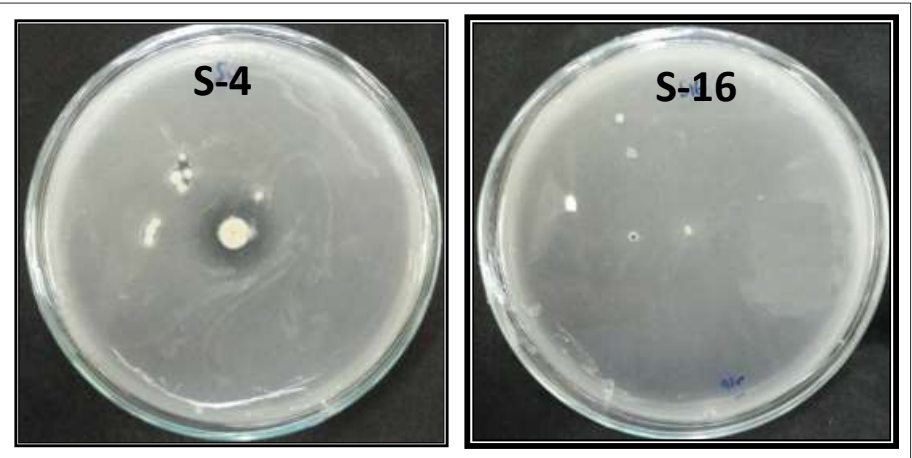

Figure 2. Results of the Antagonism of Streptomyces sp. against Ralstonia solanacearum on YPGA medium

Different ability between the Streptomyces sp. isolates in producing inhibitory compounds is possible because of the differences in strains of each isolate. This can be seen from the results of utilization and remodel of carbon sources, citrates and nitrates compounds (Table 2), where the isolates from the two groups of bacteria have differences in several tests. Pindi et al. obtained similar results, in which 7 isolates of Streptomyces spp. used in the study showed different antimicrobial activity against the 9 microbes tested [3].

Based on the molecular identification, Streptomyces sp. S-16 isolate has a similarity with Streptomyces diastaticus subsp. ardesiacus strain NRRL B-1773. Not much information that states the use of Streptomyces diastaticus subsp. ardesiacus as a biological control agent. Therefore further research is needed in controlling $R$. solanacearum in plants. This is because Streptomyces is one of the producing antibiotic compounds bacteria. A lot of useful antibiotics are derived from antibiotics produced by Streptomyces species which are also potentially antagonistic and are toxic to several pathogens [3] [4] [7].

The absence of inhibition zones in Streptomyces sp. S-16 isolate cannot indicate that this isolate cannot be used as biological control agents. Similarly, Saputra et al. [16] reported that only one isolate of Bacillus sp., i.e. Ba-1 isolate of five tested isolates showed inhibition zone in vitro, and it did not show a good ability to inhibit $R$. solanacearum in tomato plants.

\section{Conclusions and Recommendation}

Both of Streptomyces sp. isolates had several different physiological and biochemical characteristics and had a different ability to inhibit $R$. solanacearum in vitro. Streptomyces sp. 
S-16 isolate has a similarity with Streptomyces diastaticus subsp. ardesiacus strain NRRL B1773 based on the molecular identification results. Further research needs to be done to see the potential inhibition of the two Streptomyces isolates in inhibiting the development of bacterial wilt disease in tomato plants caused by $R$. solanacearum.

\section{Acknowledgments}

This research was supported by the Directorate General Higher Education, Ministry of Education and Culture the Republic of Indonesia by agreement Number 108/SP2H/PL/Dit.litabmas/IV/2004 dated 30 April 2014. The authors say many thanks.

\section{REFERENCES}

[1] K. Flardh and M. J. Buttner, "Streptomyces Morphogenetics: Dissecting Differentiation in a Filamentous Bacterium", Nature Review Microbiology 7: 36-50, 2009.

[2] R. D. Hastuti, Y. Lestari, R. Saraswati, A. Suswanto and Chaerani, "Capability of Streptomycess spp. in Controling Bacterial Leaf Blight Disease in Rice Plant", American Journal of Agricultural and Biological Sciences 7: 217-223, 2012.

[3] P. K. Pindi, G. Balakrishna and A. S. Shanker, "Isolation and Characterization of Actinobacteria from Forest Soil of Mahabubnagar District of Andhra Pradesh, India", Int. J. Pharm \&/Ind. Res 2: 63-67, 2012.

[4] T. S. Williams, M. Goodfellow and G. Alderson, Genus Streptomyces Warksman and Henrici, dalam Bergeys Manual of Systematic Bacteriology, Diedit oleh M.E. Williams \& J.G. Holt, London: Williams and Wilkins, hal. 2452-2492, 1989.

[5] G. H. S. Bonjar, S. Zamanian, S. Aghighi, P. R. Farrokhi, M. J. Mahdavi and I. Saadoun, "Antibacterial Activity of Iranian Streptomyces coralus Strain 63 Against Ralstonia solanacearum", Journal of Biological Sciences 6: 127-129. 2006.

[6] M. F. de-Oliveira, M. G. da-Silva and S. T. V. Sand, "Anti Phytopathogen Potential of Endophytic Actinobacteria Isolated from Tomato Plants in Southern Brazil and Characterization of Streptomyces sp. R18(6), a Potential Biocontrol Agent", Microbiology 161: 565-572, 2010.

[7] T. Arwiyanto, Supriadi and M. Januwati, Pengendalian Biologi Penyakit Layu Bakteri Jahe dengan Streptomyces spp., Laporan Hasil Kegiatan, Lembaga Penelitian dan Pengabdian kepada Masyarakat UGM bekerjasama dengan Badan Penelitian dan Pengembangan Pertanian. 2009,

[8] A. C. Hayward, Biology and Epidemiology of Bacterial Wilt Caused by Pseudomonas solanacearum", Annual Review of Phytopathology 29: 65-87, 1991.

[9] E. Yabuuchi, Y. Kosako, I. Yano, H. Hotta and Y. Nishiuchi, "Transfer of Two Burkholderia and an Alcaligenes Species to Ralstonia Genus nov.: Proposal of Ralstonia pickettii (Ralston, Palleroni and Douderoff 1973) comb.nov., Ralstonia solanacearum (Smith 1896) comb. nov. and Ralstonia eutropha (Davis 1969) comb. nov.”, Microbiology and Immunology 39: 897, 1995.

[10] S. Maji and P. K. Chakrabartty, "Biocontrol of bacterial wilt of tomato caused by Ralstonia solanacearum by isolates of plant growth promoting rhizobacteria", Australian Journal of Crop Science 8: 2008-214, 2014.।

[11] R. A. Lelliot and D. E. Stead, Methodes for The Diagnosis of Bacterial Diseases of Plant. Melbourne: British Society for Plant Pathology by Blackwel Sscientific Publication, 1987. 
[12] W. Chun and A. K. Vidaver, Gram Positive Bacteria: Bacillus, dalam Plant Pathogenic Bacteria $3^{\text {nd }} e d$, Diedit oleh N.W. Schaad, J.B. Jones \& W. Chun (Eds), Minnesota: APS Press, Hal. 250-260, 2001.

[13] I. Berlian, Analisis Petogenesitas dan Karakterisasi Keragaman Genetik Banana Blood Disease Bacterium (BDB), Tesis: Universitas Gadjah Mada, 2012.

[14] T. Arwiyanto, "Pengendalian Hayati Penyakit Layu Bakteri Tembakau", Jurnal Perlindungan Tanaman Indonesia 5: 54-60, 1997.

[15] A. J. Salle, Fundamental Principle of Bacteriology, $7^{\text {th }}$ ed. New Delhi: Tata McGraw-hill Publishing Company LTD, 1979.

[16] R. Saputra, T. Arwiyanto and A. Wibowo, "Test Antagonistic Activity of Some Isolates Bacillus spp. Against Bacterial Wilt (Ralstonia solanacearum) in Some Tomato Varieties and their Identification", Pros of Indon Biodiv Model, vo. 1, no, 5, p. 1116-1122. DOI: 10.13057 / psnmbi / m010525, 2015. 